\title{
A Primer on Exporting to Bolivia1
}

\author{
Christina D. Storz, Timothy G. Taylor, and Gary F. Fairchild ${ }^{2}$
}

\section{Introduction}

Every year the U.S. Department of State publishes extensive Country Commercial Guides for a large number of countries. These guides provide a great deal of information useful to individuals interested in developing export markets either through direct exports or through direct foreign investment. This paper provides an abridged version of the Country Commercial Guide for Bolivia as well as supplemental information of direct relevance to agribusiness firms. It is hoped that the information contained in this report provides a useful starting point for individuals interested in exploring export or investment opportunities in Bolivia.

Note: County Commercial Guides are available for U.S. exporters from the National Trade Data Bank's CD-ROM or via the Internet. Please contact Stat-USA by telephone (1-800) STAT-USA for more information. Country Commercial Guides can be accessed via the World Wide Web at http://www.stat-usa.gov, http://www.state.gov, and http://www.mac.doc.gov. They can also be ordered as a hard copy or on diskette from the National Technical Information Service (NTIS) by telephone (1-800) 553-NTIS. American exporters seeking general export information/assistance and country-specific commercial information should contact the U.S. Department of Commerce, Trade Information Center by telephone (1-800) USA-TRADE; or by fax (202) 482-4473.

\section{Economic and Political Overview}

The commitment of Bolivia's successive governments to the free-market economic system for the last 18 years, following the trauma of hyperinflation in the early 1980 s, has created conditions that have led to a period of steady economic growth up to 1999 . This growth has been largely non-inflationary, thanks to the Bolivian Central Bank's strict control of money supply growth. The rate of economic growth over the last several years has been disappointing, and its distribution has been uneven across the population. Bolivia remains the poorest country in South America, with a significant portion of its population participating only marginally in the formal economy. The government of Bolivia projects that its GDP (Gross Domestic Product) will grow by between $2.5 \%$ and $3 \%$ for 2003 , with nominal GDP equaling roughly US $\$ 7.5$ billion. Inflation in consumer prices continues to be low, increasing in 2002 by $3 \%$ and in 2001 by less than $1 \%$.

1. This is EDIS document FE504, a publication of the Department of Food and Resource Economics, Florida Cooperative Extension Service, Institute of Food and Agricultural Sciences, University of Florida, Gainesville, FL. Published February 2005. Please visit the EDIS website at http://edis.ifas.ufl.edu.

2. Christina D. Storz, Research Assistant; Timothy G. Taylor, Professor; and Gary F. Fairchild, Professor, Department of Food and Resource Economics, Florida Cooperative Extension Service, Institute of Food and Agricultural Sciences, University of Florida, Gainesville, FL. 
Bolivia has a relatively low level of industrialization and remains highly dependent on imports (especially capital and consumer goods) and foreign direct investment (FDI). The United States is Bolivia's largest trading partner: in 2002, the United States exported goods worth US\$283 million to Bolivia and imported goods worth US\$162 million. The United States is also the single largest investor in Bolivia, with a stock of investment of about US\$2.1 billion at the end of 2002, which represents approximately $37 \%$ of total FDI.

Bolivia welcomes foreign direct investment throughout its economy, with very few restrictions. The Investment Law guarantees national treatment and the free convertibility of currency; a U.S.-Bolivia Bilateral Investment Treaty that came into effect on June 7, 2001, provides the means for U.S. investors to defend these rights. Nonetheless, public cries for changes to laws (most recently to the Hydrocarbons Law) are frequent, most often opposing political entities, but also from Government coalition partners. Potential investors should also note that Bolivia's judicial system lacks transparency and enforcing contracts through the courts can be difficult. Incidents of corruption are also not uncommon among low-level officials of the executive branch.

The best prospects for U.S. trade and investment in the coming years are in the hydrocarbon, manufacturing, and telecommunications sectors. The Andean Trade Promotion and Drug Eradication Act (ATPDEA) in August of 2002 opened up new possibilities for investment in the area of textiles, which now enjoy duty-free access to the U.S. market, subject to an annual regional cap. In April of 2003, the Bolivian Government announced a plan to take greater advantage of ATPDEA, especially in the textile and wood products industries, that should begin to be implemented by late 2003 .

The agricultural sector has experienced impressive growth as land in the Department of Santa Cruz is being shifted increasingly to the production of soy, sunflower seed, and sugar. Bolivia exports soy and oilseed products, principally to Colombia and Venezuela under the Andean Community tariff regime. However, the past year was difficult for farmers due to poor weather conditions and decreasing soy prices, which slowed agricultural growth. The agricultural sector, principally in the Santa Cruz region, enjoyed annual growth rates of over $9 \%$ between 1994 and 1998, but dropped to less than 1.5\% growth during 1999 and 2001. In 2002 the sector grew by $0.6 \%$. Bolivian farmers have faced a credit crunch in recent years, causing some farmers to resort to pre-selling crops to processing facilities as a form of quasi-financing, a situation exacerbated by economic stagnation since 1999 , with yearly financing estimates running as high as US\$50 million. New investments and new technologies in this sector could greatly boost future production.

\section{Marketing U.S. Products and Services}

There are a number of factors that should be considered in exporting products to Bolivia. This section provides a brief overview of many critical factors that must be considered.

\section{Establishing a Business}

Foreign investments are welcome in Bolivia. Although there are specific laws designed to minimize the bureaucratic hurdles to establishing an office in Bolivia, we strongly suggest that companies hire the services of a local attorney to avoid unnecessary delays and pitfalls. The corporation, private company, or branch office are the most common vehicles for foreign investment.

Taxation on foreign companies is similar to that for local companies. Since 1995, all companies face a tax equal to $25 \%$ of profits. American companies can use the tax paid in Bolivia as a tax credit in the United States under the worldwide income taxation system. Companies should consult a knowledgeable accounting firm in Bolivia for more detailed information.

\section{Distribution / Sales Channels}

The population of Bolivia is now mainly urban, with $69 \%$ of all inhabitants living in the cities of $\mathrm{La}$ Paz/El Alto (29\%), Santa Cruz (22\%), and Cochabamba (18\%). Most companies are located in La Paz, with sales agents in the other two major cities. However, Santa Cruz, Bolivia's fastest 
growing city and major economic center, may prove to be an attractive market base in Bolivia for many companies.

The most common method of distribution is the appointment of representatives. Distribution through local subsidiaries or branch offices has also become very popular.

Transportation is an important factor to be considered in making marketing strategies. Because Bolivia is landlocked, merchandise must be delivered through seaports in Chile, Peru, Brazil, and Argentina, or by air. Occasional bad weather, roadblocks, and port congestion are possible complications that may be encountered when using ports in these cities. As a result, air cargo transportation may be preferable even for heavy items.

\section{Agents / Distributors: Finding a Partner}

Bolivian law does not require the use of local distributors for private sector commercial sales. However, most government purchases call for local agents. Agents are required to have a minimum paid-in capital of US $\$ 2,000$ to initiate a business transaction in Bolivia. Agents must also meet certain other requirements and register with the National Chamber of Commerce, the Internal Revenue Service, the Vice Ministry of Industry and Commerce, the National Directory of Commerce, and the Municipality in which they are based. To register, agents and representatives require a letter or agreement from a firm appointing them as its agent or representative. This document should clearly indicate the contract's period of validity, the sales area covered by the agent (be it national or regional), the financial terms, and whether the exporting firm has the right to appoint other agents in other areas of the country. Legal counsel is recommended in drawing up the contract, which enables the agent to act on behalf of the foreign firm in government tenders.

It is important to be thorough in the selection of an agent or representative; companies might therefore wish to take advantage of U.S. Department of Commerce services by contacting the nearest Commerical Service Export Assistance Center (EAC) in the United States. Services offered by EAC and the U.S. Embassy in La Paz include the International
Partner Search (IPS), which helps identify interested agents and distributors; the Gold Key Service (GKS), which identifies potential distributors and arranges meetings with them; and the International Company Profile (ICP), which reports on the credit and business history of individual companies.

\section{Performing Due Diligence}

American businesses considering exporting to or investing in Bolivia are recommended to investigate their potential clients, associates, or partners. The International Company Profile (ICP) program of the U.S. Commercial Service can provide a background check on the reliability of potential clients or partners. The ICP report includes information on the company's owners, year established, size, sales, financial information, and reputation in the market.

\section{Direct Marketing}

Direct marketing among financial institutions is fairly well established in Bolivia. Databases for direct marketing are not freely available. Commercial information can be obtained through the local chambers of commerce, trade associations and the Commercial Section of the U.S. Embassy in La Paz.

\section{Franchising}

Bolivia has no specific legislation regarding franchising; however, there are clear rules governing its operation. A foreign-based company wanting to grant a specific franchise in Bolivia must first register the brand name with the office of National Intellectual Property Service (SENAP). Once the brand name is registered, the foreign company may grant the local company a franchise through a contract specifying the terms of mutual agreement.

\section{Joint Ventures / Licensing}

A joint venture in Bolivia is defined as a specific business venture carried out by two or more parties with separate legal licenses. Once the objectives are clearly defined, a contract is signed between the parties, and each party becomes liable for debts according to the percentage each owns. The separate business interests of any party are not affected by the joint venture's activities unless specifically stated. Corporations and/or individuals (foreign or domestic) 
may enter into joint venture agreements. While foreign companies are not required to possess a local legal license in advance, they must be able to demonstrate their legal status in their country of origin. The Investment Law governs the operations of joint ventures and its implementing regulations are laid out in Supreme Decree 22526 (June 13, 1990).

\section{Selling Factors / Techniques}

Price-competitive products from Asian countries (e.g., Taiwan and Korea) are very popular in Bolivia. Because of this, price is an important selling factor. Quality is, however, an important factor in capital goods, electronics, and construction machinery. Most representatives in La Paz have small regional offices in Santa Cruz and Cochabamba. The rest of Bolivia is under-populated and does not offer an attractive market for many imported goods.

\section{Advertising / Trade Promotion}

The Bolivian advertising industry has become increasingly professional and competitive. The tremendous increase in private television ownership in recent years has prompted the industry to devote special attention to television commercial spots. La Paz remains the principal advertising center. Nine advertising agencies operate in La Paz, all of which are members of the Chamber of Advertising Agencies. Advertising agencies usually charge a 15\% commission, although this percentage is negotiable.

Radio has the largest audience of all communications media in Bolivia, reaching even the most isolated areas where electricity is unavailable. Newspapers have the second largest audience of all communications media in Bolivia. The five newspapers in La Paz have a combined daily circulation of between 30,000 and 80,000 copies. Television has become increasingly available to rural audiences. All TV stations are in private hands except for one government-owned national broadcasting station and those belonging to the major state universities. Access to cable television is still limited; serving approximately 30,000 homes in different areas of Bolivia.

\section{Sales Service / Customer Support}

The competitive advantage of U.S. products against similar European and Japanese products is in price, quality, reputation, and customer support. Service and maintenance provided by local agents of U.S. companies are probably the most important competitive factors. American suppliers have traditionally provided after-sales service by training their local agents.

\section{Product Pricing}

Bolivia enjoys an open market, with the government of Bolivia imposing price controls only on petroleum products. Municipal governments set prices of some basic consumer goods such as bread, meat, and vegetables.

\section{Selling to the Government}

Since 1999, the control of the most significant entities once owned by the Bolivian Government has been in private (mostly foreign) hands. Government expenditures, however, still account for a significant portion of Bolivia's GDP. The central government, the regional governments (the prefectures and municipal governments), and other government agencies remain important buyers of machinery, equipment, and materials as well as of other products and services. They are legally required to call for bids when proposed purchases are above US\$8,000. Although any local or foreign firm can present proposals for government bids, only those firms legally established under Bolivian law may sign contracts for government purchases.

Bid specifications containing technical and commercial requirements are made available through the relevant government entity and are published in the local media and at http://www.sicoes.gov.bo. The qualifying procedure and the awarding decision are entirely in the hands of the chief executive officer of the public entity involved. Domestic goods and services receive a $10 \%$ preference in any bidding to encourage local industrial development. Both the price and the quality of the product/service should be considered when awarding the contract. 


\section{IPR Infringement Protection}

A foreign company wishing to protect its product, trademark, or name in Bolivia must first register with the National Industrial Property Service (SENAPI). Protection of intellectual property rights (IPR) in Bolivia falls short of U.S. and international standards. IPR enforcement is inconsistent at best; companies should be prepared to defend their IPR aggressively.

\section{Need for a Local Attorney}

You will need a local attorney to establish a company in Bolivia or to register a brand name with SENAPI; local legal counsel is always highly recommended when doing business in Bolivia. A complete list of patent, commercial, general practice attorneys is available in the Commercial Library of the U.S. Embassy in La Paz and on the U.S. Embassy website.

\section{Trade Regulations and Standards}

\section{Trade Barriers}

The following list describes the charges imposed on imports in Bolivia, including tariffs, domestic taxes, and Customs fees. Bolivian import charges, including domestic taxes (most of which are creditable) and fees, range from $30 \%$ to $45 \%$, making the effective cost of imports considerably higher than the stated $0 \%$ to $10 \%$ tariff.

The various components of the landed cost of an import to Bolivia include:

- Cost, Insurance and Freight (CIF): The value at the border of the imported product.

- Inspection Company Fees: As of July 1, 2003, The Bolivian Customs Office (Aduana Nacional de Bolivia) is in charge of all verifications at point of destination according to guidelines of the World Trade Organization. There is no cost for this verification; however, this might be revised in the future. The Bolivian Government no longer requires point of origin verifications.

- Custom Tariff: A $10 \%$ flat rate is applied to CIF unless the product is classified as a "capital good", in which case the rate is $0 \%$ or $5 \%$. On
March 23, 2001, Bolivia implemented a new Customs regulation by which all turnkey imports of equipment and machinery from countries outside the Andean region have zero duty.

- Custom Warehouse Fee: Customs warehouses are privately owned. Rates vary depending on volume.

- Internal Revenue Service Fees: The value-added tax (IVA) is 13\%; added Customs fees bring the effective rate to $14.94 \%$, which is charged on the accumulated base (items $1+2+3+4+7+8+9$ ). This tax can later be offset against the importer's value-added tax liability on resale.

- Specific Consumption Tax (ICE): The ICE is charged at an additional percentage rate on the accumulated base if the product is defined as a "luxury good". This affects product lines such as liquors, cigarettes and beer. Tax rates may be obtained at http://www.sidunea.aduana.gov.bo.

- Customs Forms and Fees: There are no Customs fees related to forms. The new Customs entry procedures and payment of duties are performed via the Automated System Customs Data (ASYCUDA), which allows brokers and exporters to submit via Internet the Customs declaration. The cost of this service is US\$1.50.

- Customs Broker Charges: The following rates are applied to CIF for land cargo and CIF airport value for air cargo, as Customs broker fees (in addition, Customs brokers charge $17.65 \%$ on the value of their total bill to cover their own IVA tax liability):

- US\$1 to US\$10,000 = 2\%

- US $\$ 10,001$ to $\mathrm{US} \$ 20,000=1.5 \%$

- US $\$ 20,001$ to US $\$ 30,000=1.25 \%$

- US\$30,001 to US\$50,000 = 1\%

- $\mathrm{US} \$ 50,000$ to $\mathrm{US} \$ 100,000=0.75 \%$

- US $\$ 100,001$ and above $=0.50 \%$ 
- Trade and Industry Associations: Such groups as the Chambers of Commerce, Industry and Construction charge an additional fee of between 0.03 and $0.04 \%$ of CIF.

\section{Customs Valuation}

The Bolivian Customs Authority has been reformed and modernized over the last several years, with help from international donors. As a result, Customs procedures are almost completely automated. Local Customs tariff rates may be found online at http://www.sidunea.aduana.gov.bo.

\section{Standards}

The Bolivian government has no specific standards required for imports. The National Certification and Standardization Organization (IBNORCA) is in charge of developing Bolivian product standards.

\section{Labeling Requirements}

Labeling requirements for food products were established in 2002. Although products normally retain their original labels, complementary labeling, showing the importer or distributor's taxpayer identification number (RUC) and translation of ingredients into the Spanish language, is now required.

\section{Temporary Entry Provisions}

Legally established companies in Bolivia can be incorporated into the Temporary Importation for Exports Regime (RITEX) that allows entry without import tariffs of raw materials and intermediate goods to Bolivia for exclusive use in manufacturing processes for making products for export.

Bolivia is a landlocked country that uses ports of entry in Chile, Peru, Brazil, Argentina, Paraguay, and Uruguay (by river) through free transit agreements with these countries. Arica (Chile) is generally considered to be the best port of entry. Other main ports are Antofagasta (Chile), Matarani and Ilo (Peru), Santos (Brazil), and Rosario (Argentina). Bolivian Customs maintains warehousing facilities in each of these ports, where incoming goods may be stored for up to 90 days. The charge for Customs storage is $0.5 \%$ of CIF for each 30-day period or fraction thereof. Once clearing documents are signed, goods must be removed from storage within eight days to avoid an additional charge of $2 \%$ of CIF.

\section{Import Controls}

The following documents are required for imports:

- Document Description Form (Form 135).

- Invoice.

- Bill of lading (when applicable).

- Proof of insurance.

- Certificate of inspection issued prior to shipment (when applicable).

- Port expenditures (when applicable).

- Transportation invoice.

- Packing list.

- Certificate of origin (when applicable).

- Certificates (when applicable).

If the product is imported from the Andean Community (Colombia, Venezuela, Peru, and Ecuador), a certificate of origin is required to qualify for tariff preferences.

Samples and advertising materials are usually subject to regular duty rates, except those articles specifically prepared as samples. Commercial samples not exceeding US\$25 in value do not require commercial invoices.

Products requiring import licenses include firearms, munitions and explosives imported by private persons, and chemical precursors that are applicable to cocaine production. A complete list of these products may be found online at http://www.sidunea.aduana.gov.bo.

Either exemptions or reductions in duties are permitted for imports made under current international agreements and government contracts; imports under intra-regional agreements that specifically provide for duty exemptions; imports 
made by the diplomatic and consular corps; traveler's personal effects not exceeding US $\$ 300$; and imports of gold, except jewelry.

Special documentation is required for the following imports:

- Sanitary and Purity Certificates for Livestock: Certificates of origin indicating the livestock's state of health is required for the import of live animals. Purebred livestock imported for breeding purposes also require a pedigree certificate. Live plants and all seeds require sanitary certificates.

- Sale Permit Certificate for Insecticides: Prior to import or sale, the Vice Ministry of Agriculture and Livestock (VMAG) must approve all insecticides. The VMAG will issue a sale permit certificate for products previously approved in their country of origin.

\section{- Sanitary Certificate for Food Products: Food} shipments require a sanitary certificate issued by the pertinent authority of the exporting country (e.g., the U.S. Department of Agriculture). Foodstuffs may be subject to analysis by an official entity in Bolivia, and most food and beverage labels must be registered in Bolivia. Exporters are encouraged to check with importers regarding relevant policies prior to shipment.

- Air Cargo: Air cargo shipments require airway bills instead of bills of lading. Follow IATA or ICAO rules governing labeling and packaging of dangerous and restricted goods. Check with your air carrier for further information and the appropriate forms.

- Parcel Post: An authorized Customs broker must intervene for parcel post shipments valued at over US\$100. A private person may receive parcel post valued up to US $\$ 100$ without the intervention of a Customs broker just by filling out a Customs form at the post office.

Prohibited items for import include spoiled or adulterated beverages and food products, or products that contain noxious substances; selected liquors, such as pisco and similar products; diseased animals; plants, fruits, seeds and other vegetables that contain parasites and germs or plants that are declared harmful by the Vice Ministry of Agriculture; and certain chemical products without the proper import permit.

- Insecticide Products: There is no production of insecticides in Bolivia; all insecticides are imported. Prior to import or sale, all insecticide products must have a sales permit certificate granted by SENASAG's (Bolivia's sanitary/phytosanitary authority) Pest and Fertilizer Division and a sanitary certificate approved by the National Institute of Occupational Health. Both certificates will allow foreign insecticides to be freely sold in the local market.

- Tobacco Products: Bolivia does not impose any restrictions for the importation of tobacco and tobacco products. However, an import license is required from the Ministry of Health and the National Service for Food Safety and Security (SENASAG). The import permit must be obtained prior to shipping. Tobacco and tobacco products are also considered luxury items, which means the specific consumption tax (ICE) is applied as well as an additional import tax of $50 \%$ ad valorem.

- Treated or Non-Treated Seeds: All products or sub-products of vegetable origin must obtain a certificate granted by the National Service for Food Safety and Security (SENASAG).

Imported seeds must, whatever the variety, have a phytosanitary certificate issued by the agricultural authorities of the country of origin. The Bolivian importer must present the phytosanitary certificate of the country of origin, certified by a Bolivian Consulate. This certificate must be presented before the Customs authorities at the port of entry. The importer must inform the Customs authorities of the arrival date of the seeds at least one week in advance. The seeds must be placed in an adequate warehouse for inspection by Bolivian agricultural authorities. The inspection must take place before the seeds are sold or used directly by the importer. The seeds must comply with the required quality and 
phytosanitary requirements of the National Seed Program and SENASAG respectively before the seeds can be marketed.

- Fishery Products: A sanitary health certificate is required for entry of imports of perishable products (e.g., seafood). There are other technical requirements (e.g., product specification standards and labeling and marking standards).

\section{Export Controls}

To become a legal exporter from Bolivia, the interested company must obtain a legal solicitorship. Once the solicitorship is obtained, the local company must register with SIVEX (Sistema de Ventanilla Unica del Exportador), the exporter's "one-stop" system at the Vice Ministry of Industry and Commerce and Exports of the Ministry of Economic Development.

In order to export, the exporter must first present the following documents: a commercial invoice and a packing list. Next, Customs issues an exporter's bond. If the exported product is animal or vegetable, a sanitary certificate must be obtained from the Vice Ministry of Agriculture and Livestock.

SIVEX then grants the certificate of origin, which makes the exporter eligible for duty-free treatment in countries offering Bolivia duty-free benefits.

\section{Free Trade Zones / Warehouses}

Bolivia has established nine Free Trade Zones (FTZ), six of which are now in full operation: El Alto (serving La Paz), Puerto Aguirre (near Puerto Suarez, on the border with Brazil), Cochabamba, Santa Cruz, Oruro, Desaguadero (near La Paz, on the border with Peru), and two others in San Matias in the Department of Santa Cruz and Guayaramerin in the Department of Beni that are not yet fully operational. Another, Cobija, in northern Bolivia, has not proven to be attractive to investors because of the lack of roads and other basic infrastructure.

\section{Membership in Free Trade Agreements}

Bolivia signed a Free Trade Agreement with MERCOSUR (Brazil, Argentina, Paraguay, Uruguay, and Chile), which became effective on March 1, 1997. Under the Agreement, Bolivia became an associate member of MERCOSUR, just as Chile is. In March of 1997 more than 30\% of all products traded between Bolivia and the four full MERCOSUR members became tariff-free, and the vast majority of the remainder will enjoy zero tariffs after ten years. (Some sensitive products will not become tariff free for up to 18 years.)

Bolivia is also a member of the Andean Community (with Colombia, Venezuela, Ecuador, and Peru), which has reduced significantly most of the internal trade barriers. Bolivia has signed Bilateral Trade Agreements with some South American countries that eliminate or reduce tariffs on explicit lists of products. Bolivia signed a free trade agreement with Mexico in September of 1994. The European Union, Japan, and the United States allow most Bolivian exports to enter their markets at either duty-free or reduced duty rates. Bolivia acceded to the General Agreement on Tariffs and Trade (GATT) in 1989 and ratified its membership in September 1990. The Bolivian Congress subsequently ratified Bolivia's membership in the World Trade Organization (WTO) in 1995.

\section{Investment Climate in Brief}

- Foreign ownership is allowed virtually throughout the economy, with no requirement to register foreign direct investment separately.

- Investments often do not receive the full protection offered by law due to inconsistent or arbitrary decisions by regulators, an easily corrupted and influenced justice system that can deny legal due process, and arbitrarily unfavorable interpretations of laws and regulations by government officials.

- The Investment Law (Law 1182, 1990) guarantees foreign investors will receive national treatment, have access to free currency conversion, and enjoy unrestricted remittance rights to international arbitration in most industries. 
- The Agrarian Law (Law 1715, 1996) set out the rights and obligations of land ownership, incorporated the concept of sustainable development, established a new institutional framework for the development of land use, and created an independent Agrarian Superintendent to administer the law's provisions. A definitive registry of land titles (essential to the provision of credit) continues to be compiled.

- There is free currency conversion at local banks and exchange houses. The official exchange rate is set by a daily auction of dollars managed by the Central Bank.

- Article 22 of the Bolivian Constitution provides that property may be expropriated for the public good or when the property does not fulfill a "social purpose"; it also stipulates that just compensation must be provided.

- The Bolivian government does not impose any performance requirements as conditions for establishing, maintaining, or expanding business establishments. Nor does it provide tax or investment incentives that discriminate against foreign investors.

- Bolivian bankers are slowly developing in-house capabilities to adjudicate credit risk and to evaluate expected rates of return according to international norms.

- Bolivia is prone to periods of social unrest that can often turn violent and disrupt the transportation of people and goods on the country's principal highways.

- Bolivia has a significant corruption problem in both the public sector and in many other non-governmental institutions.

- An Investment Insurance Agreement signed in 1985 by Bolivia and the U.S. Overseas Private Investment Corporation (OPIC) provides for a full range of OPIC programs, including insurance, financing, and use of OPIC's Opportunity Bank.

- About half of Bolivia's 8.3 million population is considered "economically active" (working at least one hour a week), a figure that includes young teenagers and children who are formally prohibited from working by law. Foreign investors have found the labor force to be stable, with low rates of turnover and high levels of manual dexterity. The country's generally low levels of education and literacy tend to limit the productivity of Bolivia's labor force, in line with its low cost. There is abundant manpower readily available for foreign and domestic investors, although skilled manpower is harder to find.

- The government sets a minimum monthly wage each year; currently it is about US\$60, although nearly all workers in the formal private sector earn more than the minimum wage. On average, factory workers earn the equivalent of US\$100 per month plus benefits.

\section{Business Customs}

\section{Travel Advisory and Visas}

Any foreigner wishing to work in Bolivia must first obtain a permit ("Carnet Laboral") from the Ministry of Labor. To obtain this permit, the foreigner must file an application with the Ministry of Labor and have a passport with a valid visa (paperwork takes about one month to be processed). Bolivia has three non-immigrant visa categories: Tourist Visa, Temporary Residence Visa, and a Permanent Residence Permit.

Temporary and permanent resident visas cover principals, managers, and trained and specially-qualified employees who are involved in the company's operations. No special qualifications are required for entry into Bolivia. An individual is not limited in the type of work that can be performed once a visa is granted. There are no requirements on the amount of money invested to qualify for entry.

There are no specific restrictions on an investor wishing to live and work in Bolivia once a residence visa is granted. The spouse and children of the visa holder are entitled to enter the country with the visa holder provided their names are included in the legal petition presented to the Director General of Immigration. 


\section{Business Infrastructure}

The importance of occasional personal visits from company representatives, as well as prompt, responsive handling of communications, cannot be overstated, given the key role played by local representatives. After a business relationship has been established, local distributors and agents generally expect to receive an offer to visit the foreign company's plant facilities and head offices to become better acquainted with the company's personnel and operating techniques.

Although capitalization and privatization have placed most of the former government-owned enterprises into private hands, Bolivia's economy still remains highly influenced by decisions taken in the public sector. Businesses should be prepared to deal with government officials and their sometimes-convoluted procedures. American exporters or shippers should adhere closely to the instructions of the Bolivian importer, as well as to the instructions laid out in the "trade regulations" section of this report, regarding shipment of goods in order to avoid difficulties and customs fines.

Regrettably, business practices in Bolivia's government and local business sectors can involve different sets of standards than are common in the United States and some that might be illegal or unethical under U.S. law. American companies should exercise the utmost care and discretion in their business dealings and should go to the Embassy for advice on how to proceed if confronted with corrupt practices.

Transportation is hindered by a lack of developed infrastructure. Bolivia has 60,282 kilometers $(\mathrm{km})$ of roads, of which only $4,101 \mathrm{~km}$ are paved, 18,302 km are gravel, and 37,878 km are dirt roads. The Bolivian national railroad system has a total of $3,960 \mathrm{~km}$ of track, divided into two non-connecting segments. The western segment is 2,500 km long and serves the Pacific ports of Arica and Antofagasta (Chile) as well as the lake port of Guaqui and the major cities in the Altiplano and the Andean valleys. Much of the western segment of the rail system is in disrepair. The eastern segment is 1,460 km long and links Santa Cruz with Brazil and Argentina. There are airline connections to other
Latin American countries and to Miami out of La Paz and Santa Cruz.

Utilities throughout the country are good, with reliable electric power in the major cities. Water shortages may occur in the dry season in various parts of the country, including La Paz and Cochabamba. Water is not potable by U.S. standards in any Bolivian city, although the major cities have improved the quality of their water supply systems in recent years.

National and international telephone services are available in La Paz and even in rural towns, but cost much more than in neighboring countries. Direct dialing is available throughout the country. Most business establishments have fax and telex machines, with electronic mail becoming increasingly popular. The Internet has been operational in Bolivia since 1996.

Spanish is both the official language and the language of commerce in Bolivia. Although Aymara and Quechua are also spoken extensively, Spanish is understood in all but the most remote parts of Bolivia. English is also widely spoken among business leaders and public officials, though most prefer to speak Spanish.

Office hours are the same throughout the year but vary somewhat from city to city. In La Paz and Cochabamba, office hours are 9 a.m. to 7 p.m.. with a two and half hour lunch break, except for government offices (which are 8:00 a.m. to 4:00 p.m., with no break at lunchtime). In Santa Cruz, the tropical climate demands that work begins and ends earlier, beginning at 8 a.m. and ending about 6:30 p.m., with a two hour lunch break in the middle of the day.

Sanitary conditions throughout the country are such that it is advisable to boil water at least 20 minutes or to consume only bottled water, refuse ice, and wash fresh fruits and vegetables with a special disinfectant or bleach. Even the best restaurants in the major cities may inadvertently serve tainted food. Americans also have been victims of e-coli and typhoid. Hepatitis and rabies are common in Bolivia, although with proper vaccinations both can usually be avoided. Malaria, leishmaniases, and yellow fever are found in the jungles in Bolivia's northern and 
eastern regions, and white leprosy and yellow fever are sometimes found in the Yungas Region of La Paz.

\section{Useful Web Sites}

\section{BOLIVIA:}

- National Chamber of Commerce

http://www.cepb.org/federaciones.Cnc.htm

- Commercial Service Export Assistance Center

(EAC)

http://www.export.gov/comm_svc/eac.html

- US Embassy in La Paz

http://lapaz.usembassy.gov/english/engindex.htm

\section{UNITED STATES:}

- USDA Foreign Agricultural Service

http://www.fas.usda.gov

- US Export Programs Guide

http://infoserv2.ita.doc.gov/ticwebsite/tic.nsf/

AF34FA880278BDD5825690D00656C6F/

F69FDCF72B7713B58525691900746F18?Open

Document

- Internet Guide to Trade Leads

http://infoserv2.ita.doc/gov/ticwebsite/tic.nsf/

504ca249c786e20f85256284006da7ab/

ef7db94aef24919885266470049c1cd?OpenDocu

ment

- US Trade Finance Resources

http://infoserv2.ita.doc.gov/ticwebsite/tic.nsf/

AF34FA880278BDD5825690D00656C6F/

F69FDCF72B7713B58525691900746F18?Open

Document

- Basic Guide to Exporting

http://www.unzco.com/basicguide/index.html

\section{HEMISPHERIC:}

- Hemispheric Guide on Customs Procedures

http://alca-ftaa.iadb.org/hgcp_eng.htm

- Hemispheric Trade and Tariff Database http://alca-ftaa.iadb.org/eng/ngmadb_e.htm 